\title{
THE EFFECT OF PROJECT MANAGER'S SOFT SKILLS ON SUCCESS OF PROJECT IN THE CONSTRUCTION INDUSTRY \\ ${ }^{1}$ Muhammad Tahir Ph.D. \\ ${ }^{1}$ Business Administration Department, Iqra National University, Pakistan ORCID: https://orcid.org/0000-0001-8195-513X
}

*Corresponding Author: Muhammad Tahir
${ }^{1}$ Corresponding Author Email: tahirkhanzaee@ gmail.com

Article Received: 05-06-19 Accepted: 20-08-19
Published: 05-09-19

Licensing Details: Author retains the right of this article. The article is distributed under the terms of the Creative Commons Attribution-NonCommercial 4.0 License (http://www.creativecommons.org/licences/by-nc/4.0/) which permits non-commercial use, reproduction and distribution of the work without further permission provided the original work is attributed as specified on the Journal open access page.

\begin{abstract}
For any project success, there are numerous factors which play its role. The hard and soft skills of project managers also plays its role in the success of a project since these skills enable project managers to better plan, execute, and evaluate project progress. The objective of this study was to identify and test the influence of soft skills of project managers on success of a project. The study design was cross-sectional and quantitative approach based. Data is collected using the convenience non-random sampling. Results indicate that among the skills set, the highly influential skills of project manager on project success include communication skills $(\beta=.394, \mathrm{P}<.05)$; team building skills $(\beta=.618, \mathrm{P}<.05)$; and problem solving skills $(\beta=.424, \mathrm{P}<.05)$.Furthermore, we did not find support for the relationship between interpersonal skills and coordination skills. The Rsquare value indicated that project managers soft skills can contribute as much as $78.3 \%$ variation in the success of a project. Our results implies that organizations need to give attention to the soft skills of a project manager
\end{abstract}

Keywords: Soft Skills, Project Success, Project Manager, Pakistan

\section{INTRODUCTION}

According to Yang, Huang, and $\mathrm{Wu}$ (2010) projects manager plays important role in success of any project. Key pillars of any project management program include profession, planning, and execution. According to Siguroarson (2009), in past project management education 
mostly focused on hard or technical skills of project manager; but now there is more focus on the inclusion of soft skills in the project manager's education. Generally, the hard skills related to the project management include planning, evaluation, monitoring, scheduling, and risk management. on the other hand, now the soft skills are gaining popularity and include ability to work with different type of people, personality traits, handling stress, leadership, conflict management, and communication (Robles, 2012; Shi and Chen, 2006). A key characteristic of soft skills is that these skills are intangible and difficult to measure. They are more associated with organizational behavior aspect and dealing with people associated with a particular project (Kirsch, 2000).

\section{Problem Statement}

The key problem this study is investigating is the low level of awareness and application of soft skills requirement of project managers for the success of a project. Mostly, construction industry hires civil engineers as a project manager who may have sound technical knowledge but may be lacking soft skills. Lack of such soft skills can decrease project manager's ability to handle projects efficiently and effectively. Lack of soft skills of project managers can also result in failure of a project. Thus, this study investigate that what role soft skills plays in the performance of project managers and how these soft skills influence success of a project.

\section{Objectives}

- To identify the gap in project manager's soft skills in terms of communication, interpersonal, coordination, team building and delegation, problem finding, analyzing and solving in the construction related projects

- To see the effect of project manager's soft skills on success of construction related projects

\section{Study Significance}

The study is beneficial for the project managers as they can use the findings to identify and improve their skills deficiency. The findings is also beneficial for the construction industry firms as these firms can devise better recruitment and selection, and training and development function based on the findings of the study. The HR managers of the construction industry can also use the findings of the present study.

\section{Projects Managers Soft Skills}

\section{LITERATURE REVIEW}

One of the important soft skills required by a project manager is leadership skills which is about ability to persuade others to accomplish pre-defined goals with zeal, enthusiasm, and willingness (Shi \& Chen, 2006; Mascia, 2012). It is a job of a project manager to act as a leader of the project and catalyze employee's skills such as planning, organizing, and decision making. Previously, there was more focus on projects manages hard skills (Byrd and Turner, 2001); how, realizing the gap, now there is greater focus on project manager's soft skills (Klaus, 2010). There is so much emphasis on soft skills of a project manager that some studies attributed it as one of the most important factor in contributing in projects success (Watts \& Watts, 2008; Mayo, 2013).

El-Sabaa (2001) stated that key project management skills include the staff mobilization, coping with difficult situation, authority delegation, exhibiting sensitivity, showing enthusiasm, and maintenance of high self-esteem. Similarly, Low and Christopher (2000) stated that project managers success skills requires the soft skills sets consisted of 
communication skills, leadership skills, interpersonal skills, flexibility and adaptability, and technical strength. Shi and Chen (2006) stated that project managers need the skills including communication, interpersonal, coordination, team building and delegation, and problem solving skills.

\section{Communication Skills}

Communication skill is one of the core skill requires by project managers for making projects successful (Shi and Chen, 2006). The communication skills include different format of communication including written and oral communication skills. A good communication skills enable project managers to understand projects teams concerns, identify problems in advance, and resolve conflicts in time (Mascia, 2012). This skill is also about understanding the communications made by others in its true sense. Studies show that communication skills are important for project managers (Jetu and Riedl, 2012). Study by Kreger (2011) also categorized communication as an important factor in project success.

Interpersonal skills is second skill requires by project manager for managing projects successfully (Brenton and Levin, 2012). This skill is about how a project manager deal with different background of people and manage relationships. Cornelius (2012) states that persuasion skill is also part of leader's interpersonal skill and is about how individual persuade and influence other so that they can support project manager in achieving projects objectives. Employee motivation is about motivating team members so that they can work hard and put energies in achieving project goal. A project manager also requires being good in motivating staff as it is also part of the interpersonal skills (Brenton and Levin, 2012).

\section{Coordination Skills}

The third skill requires by a project manager for successfully managing project is coordination skills (Brenton and Levin, 2012). This skill is about building harmonious relationships with project team members in order to complete project successfully. Coordination is also about managing different dispersed tasks, teams, parties, and internal and external stakeholders.

\section{Team building and Delegation Skills}

Deepa and Seth (2013) states that team building and authority delegation is also required by project manager to make project successful. As part of team building and delegation, a project manager is required to foster team work, develop his/her team, develop team members, put confidence on them, give them authority, and delegate tasks. Without proper team building and delegation, a project manager may end up with too much overburden.

\section{Problem Solving}

The last skill we are including in our model is problem solving. This skill is about project manages ability to identify problems in advance, analyze problems, come up with some suitable feasible solutions, and tackle problem in timely manner (Deepa and Seth, 2013). Without good problem solving skills, a project manager may identify problem too late to be solved which can reduce the chances of making project successful.

\section{Project Success}

There is a lot of discussion about project success, but there is no agreed criteria and definition of project success among scholars (Siguroarsan, 2009). Narayanaswamy, Grover, and Henry (2013) describe project success as situation when a project meets its expectations and completed within given time frame and cost. For project to successful, there are several 
factors which play its role and soft skills of the project manager is one of them (Sicotte and Langley, 2000; Hoegl and Parboteeah, 2007).

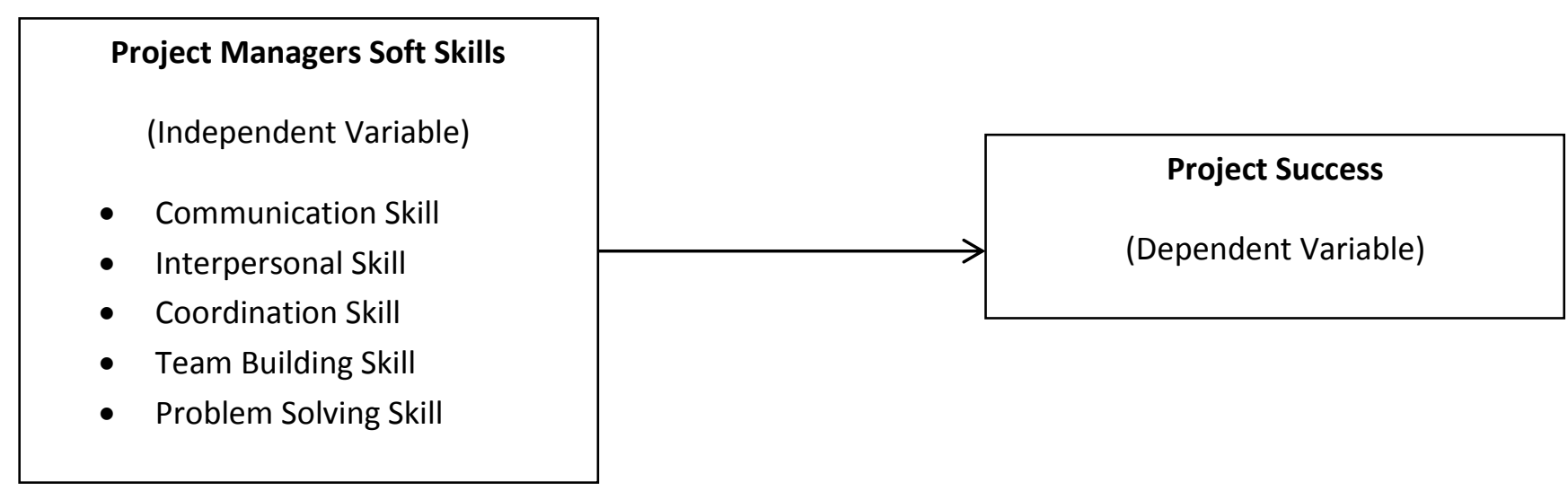

\section{Research Method}

\section{RESEARCH METHODOLOGY}

The study utilize the quantitative approach and cross-sectional research design. Accordingly, the data collection is primary and based on survey method.

\section{Population and Sampling Approach}

The focus of the study is project managers in Pakistan so all employees working at managerial and supervisory level are constituting the population of the study. For sampling, we selected convenience non-random sampling and contacted various project managers who belonged to different construction industry firms. Because of limited resources, we did not include the firm size as criteria for inclusion. We distributed total of 245 survey out of which we received 167 usable survey. The survey were filled by people who were working as project managers, assistant project managers, and included supervisory level staff.

\section{Data Collection}

The data collection method was survey method which we used for collecting primary data. The questionnaire were physically distributed and collected back. Some of the questionnaire were sent using the Google form and collected back electronically.

\section{Survey Measure}

We used adapted questionnaire for measurement. Measure for project managers soft skills was adapted from Shi and Chen (2006) consisted of 3 items for communication skill, 3 items for interpersonal skill, 3 items for coordination skills, 4 items for team building and delegation skills, and 3 items for problem solving skill.

Measure for project success is adapted from Narayanaswamy, Grover, and Henry (2013) consisted of 5 items. 


\section{RESULTS}

Table 1

Demographic Details

\begin{tabular}{llcc}
\hline & & Frequency & Percentage \\
\hline Gender & Male & 157 & 94.0 \\
Work Experience & Female & 10 & 6.0 \\
& Less than 1 Years & 15 & 9.0 \\
& 1 to 5 Years & 68 & 40.7 \\
& 5 to 15 Years & 77 & 46.1 \\
& Above 15 Years & 7 & 4.2 \\
\hline
\end{tabular}

157 participants in our survey were male and 10 participants were female. 77 participants had work experience of 5 to 15 years of work experience; 68 participants had work experience of 1 to 5 years; and 15 had work experience of less than 1 years.

Table 2

Descriptive Statistics

\begin{tabular}{lcccccc}
\hline & $\begin{array}{c}\text { Number of } \\
\text { Items }\end{array}$ & Minimum & Maximum & Mean & Std. Deviation & $\begin{array}{c}\text { Cronbach } \\
\text { Alpha }\end{array}$ \\
\hline Communication Skill & 03 & 1.33 & 5.00 & 3.7146 & .97442 & .877 \\
Interpersonal Skill & 03 & 1.33 & 5.00 & 3.6108 & .76979 & .766 \\
Coordination Skill & 03 & 1.67 & 5.00 & 3.6407 & .77182 & .813 \\
Team Building Skill & 04 & 2.00 & 5.00 & 3.6093 & .90786 & .900 \\
Problem Solving Skill & 03 & 1.67 & 5.00 & 3.7804 & .98637 & .860 \\
Project Success & 05 & 1.60 & 5.00 & 3.5677 & .92809 & .895 \\
\hline
\end{tabular}

The descriptive statistics indicate that participants who were mostly project managers had above average level of skills including communication skills $(\mathrm{M}=3.71)$; interpersonal skills $(\mathrm{M}=3.61)$; coordination skills $(\mathrm{M}=3.64)$; team building skills $(\mathrm{M}=3.60)$; and problem solving skills $(\mathrm{M}=3.78)$. Furthermore, the project success was also above average $(\mathrm{M}=3.56)$.

Table 3

Regression Analysis

\begin{tabular}{|c|c|c|c|c|c|c|c|}
\hline \multirow[t]{2}{*}{ Model } & \multicolumn{2}{|c|}{$\begin{array}{c}\text { Unstandardized } \\
\text { Coefficients }\end{array}$} & \multirow{2}{*}{$\begin{array}{c}\begin{array}{c}\text { Standardized } \\
\text { Coefficients }\end{array} \\
\text { Beta } \\
\end{array}$} & \multirow[t]{2}{*}{$\mathbf{t}$} & \multirow[t]{2}{*}{ Sig. } & \multicolumn{2}{|c|}{$\begin{array}{c}\text { Collinearity } \\
\text { Statistics }\end{array}$} \\
\hline & B & Std. Error & & & & Tolerance & VIF \\
\hline (Constant) & .471 & .197 & & 2.39 & .018 & & \\
\hline Communication Skill & 394 & .061 & .376 & 5.23 & .000 & .329 & 3.044 \\
\hline Interpersonal Skill & -.206 & .063 & -.171 & -3.26 & .001 & .496 & 2.018 \\
\hline Coordination Skill & .091 & .067 & .076 & 1.36 & .175 & .439 & 2.277 \\
\hline Team Building Skill & .618 & .072 & .605 & 8.55 & .000 & .270 & 3.702 \\
\hline Problem Solving Skill & .424 & .057 & .451 & 7.41 & .000 & .366 & 2.733 \\
\hline $\begin{array}{l}\mathrm{R}=.885 \\
\text { Rsquare= } .783 \\
\text { Fstat }=115.859(.000)\end{array}$ & & & & & & & \\
\hline
\end{tabular}

The results shows that among the skills set, the highly influential skills of project manager on project success include communication skills $(\beta=.394, \mathrm{P}<.05)$; team building skills $(\beta=.618$, $\mathrm{P}<.05)$; and problem solving skills $(\beta=.424, \mathrm{P}<.05)$. The results for interpersonal skills turned out to be negative and significant $(\beta=-.206, \mathrm{P}<.05)$; and insignificant for coordination skills 
$(\beta=.091, \mathrm{P}>$.05). The Rsquare value shows that $78.3 \%$ variation in project success can be attributed to project manager soft skills. The Fstatistics indicate good model fitness (Fstat $=115.859, \mathrm{P}<.05)$.

\section{CONCLUSION}

The objective of the study was to identify soft skills which have significant influence on project success. The study was based on Pakistani context and data is collected from project managers through convenience sampling. Results indicate that among the soft skills, communication skills, team building skills, and problem solving skills are the most important soft skills which have significant influence on project success. These results are supported by the previous studies. For example, Jetu and Riedl (2012) reported that communication skill is highly important skill and important for the success of a project. Similarly, Deepa and Seth (2013) stated that team building and delegation skills as well as problem solving skills is important for project success. Hoegl and Parboteeah (2007) found support for the role of soft skill of a project manager in the success of a project. Based on the previous studies findings, and the finding of the present study, it can be concluded that soft skills are important factor which enhance project managers knowledge and ability to better handle project related problems and effectively plan, execute, and implement project management.

\section{Recommendations}

- One recommendation is that project manager's soft skills need to be improved in order to improve chances of project success.

- Communication skill is highly important and project managers may be given appropriate training regarding communication skill.

- Project managers team building skills also need to be improved using appropriate training and counseling.

- Project managers problem solving skills need to be improved.

- During recruitment and selection process for project managers, candidate soft skills also need to be given attention.

\section{Limitations and Future Directions}

The study limitation are small sample size and focus on specific skills set. In future, a researcher may work with bigger sample and different research design such as qualitative research which may give better idea about this topic. Longitudinal study such as before and after project launch and completion can also be a useful avenue for future researchers.

\section{References}

Brenton, B., \& Levin, D. (2012). The Softer Side of Innovation: The People. Journal of Product Innovation Management, 29(3), 364-366. doi:10.1111/j.15405885.2012.00910.x

Byrd, T.A., D.E. (2013). Turner. An Exploratory Analysis of the Value of the Skills of IT Personnel: Their Relationship to IS Infrastructure and Competitive Advantage. Decision Sciences, 32(1) 21-54.

Cornelius, D. (2012). Conference Focuses on Leadership and Project Management as the Crossroads of Project Success. PM Network, 28. 
Deepa, S. S., \& Seth, M. (2013). Do Soft Skills Matter? - Implications for Educators Based on Recruiters' Perspective. IUP Journal of Soft Skills, 7(1), 7-20.

El-Sabaa, S., (2001). The skills and career path of an effective project manager. International Journal of Project Management,19(1), 1-7.

Hoegl, M., \& Parboteeah, K. P. (2007). Creativity in innovative projects: How teamwork matters. Journal of Engineering and Technology Management, 24(1), 148-166.

Jetu, F., \& Riedl, R. (2012). Determinants of Information Systems and Information Technology Project Team Success: A Literature Review and a Conceptual Model. Communication of The Association For Information Systems, 30455-482.

Kirsch, L. J. (2000). Software Project Management: An Integrated Perspective for an Emerging Paradigm. In R. W. Zmud (Ed.), Framing the Domains of IT Management: Projecting the Future...Through the Past 285-304.

Klaus, P. (2010). Communicationunication breakdown. California Job Journal, 28, 1-9.

Kreger, L. (2012). Teams Work: A Model for Project Management Success. Information Management Journal, 46(5), 45-46.

Low,S.P., Leong, Christopher, H.Y. (2000). Cross-cultural project management for international construction in China. International Journal of Project Management, 18(5), 307-316

Mayo, W. D. (2013). Soft-Side Leadership. Leadership Excellence, 30(8), 16.

Narayanaswamy, R., Grover, V., \& Henry, R. M. (2013). The Impact of Influence Tactics in Information System Development Projects: A Control-Loss Perspective. Journal Of Management Information Systems, 30(1), 191- 226. Doi:10.2753/MIS07421222300106

Robles, M. M. (2012). Executive Perceptions of the Top 10 Soft Skills Needed in Today's Workplace. Business Communication Quarterly, 75(4), 453-465. Doi: $10.1177 / 1080569912460400$

Shi, Q., Chen, J., (2006). The Human Side of Project Management - Leadership Skills, available at http://www.pmi.org/Knowledge-Center/Research-CompletedResearch/Human-Side-of-Project-Management-Leadership\%20Skills.aspx

Yang, L. R., Huang, C. F., \& Wu, K. S. (2011). The association among project manager's leadership style, teamwork and project success. International journal of project management, 29(3), 258-267 